\title{
Penggunaan Media Sosial di Kalangan Wanita Dewasa Ditinjau dari Nilai-Nilai Karakter
}

\author{
Nenden Elista Fauziatunisa \\ Psikologi Pendidikan Islam, Pascasarjana, UIN Sunan Kalijaga Yogyakarta \\ Nenden903@gmail.com
}

\begin{abstract}
The purpose of this research is to analyze and find out the dynamics of the use of social media among adult women in the formation of character values, this is both seen from the pros and cons of advances in communication technology among adult women seen from the character values, where in the present social media has it is no stranger to every circle, be it teenagers, adults or even the elderly. The research method used a qualitative approach and also Library Research. Data collection was carried out by observation, in-depth interviews with adult women of UIN SUKA postgraduate students who actively use social media. The results of the study found that social media is determined by several applications, content, and also the effect it causes in shaping the character of women. Social media in particular has a close relationship in shaping values and also personal character. Social media also reflects that the positive impact of technological advances in education is able to create good learning activities, make it easier for students to find learning resources, and with technology can help students learn to apply technology in the teaching and learning process, so that students are more interested in learning. The findings also show that the negative impact of technological development, one of which is the low character value, especially from the social aspect, and the lack of communication between students and their surroundings. Consumptive, and also tend to be ignorant of the surrounding environment.
\end{abstract}

Keywords: Social Media; Character Values; Adult Women.

\section{PENDAHULUAN}

Pertumbuhan dan juga kemajuan teknologi di masa kini sudah bertumbuh semakin pesat dari waktu ke waktu. Dengan teknologi semuanya menjadi serba unik dan efisien, dari semua ranah pekerjaan sudah mengandalakan kemajuan teknologi. Pada saat zaman dahulu teknologi informasi adalah hal yang tidak bisa kita dapatkan secara instan banyak orang yang mengandalkan koran, TV, majalah sebagai sumber pembaharuan informasi. Sangat berbeda pada zaman canggih sekarang ini setiap orang bisa mengakses kapan saja dan dimana saja melalui gadgetnya masing-masing. Informasi yang secara begitu mudah kita ambil hanya dengan satu kali klik. Kemajuan teknologi pada saat ini serta merta telah mengubah sedikit 
banyaknya cara setiap individu dalam berinteraksi satu sama lain. Internet bak menjadi tempat baru yang menciptakan sebuah ruang kultural. Sesuatu hal yang tak bisa dihindari bahwa adanya jejaring internet memberikan dampak yang begitu besar bagi penggunanya, akses informasi dari berbagai penjuru dunia dapat di cari melalui internet (Tegar, 2018).

Zaman sekarang ini teknologi informasi menjadi sebuah hal yang tidak bisa di pisahkan lagi dari kehidupan sehari-hari, mungkin pada saat jaman dahulu HP adalah salah satu barang yang tersier dan juga tergolong mewah karena tidak semua orang mempunyainya, tetapi di era digital ini HP adalah sebuah alat kumunikasi yang tidak bisa terpisahkan lagi dengan kehidupan individu. Penggunaan teknologi informasi sudah hampir seluruh bidang kegiatan dan juga usaha telah menggunakan teknologi informasi tanpa terkecuali. Dengan hal ini menunjukan bahwa teknologi modern telah mengubah peradaban manusia itu sendiri, dan akan melahirkan perbedaan yang tajam.

Kemajuan teknologi selalu diiringi dengan dampak yang positif dan juga negatif. Dimana dibalik kelebihan tentu ada kekurangan didalamnya, kita tidak bisa mengatakan bahwa media informasi itu tidak perlu, tetapi dengan menggunakan media informasi sesuai dengan penggunaanya maka itulah yang kita gunakan. Adanya Internet secara tidak langsug melahirkan sebuah kelompok atau generasi yang baru, yang disebut generasi next. Generasi ini adalah generasi masa yang akan datang yang di asuh dan pula di besarkan dalam ruang lingkup kebiasaan dan budaya baru media digital interaktif, yang dapat disebutkan bersifat desosiasi/individualistik, bekomunikasi secara mandiri, melek komputer, dibesarkan dengan videogames, dan lebih banyak waktu luang untuk mendengarkan radio dan televisi (Afriluyanto, 2017).

Berbicara mengenai sebuah kegiatan komunikasi, dihadapkan pada sebuah realita dimana seakan tidak ada batasan dan tidak adanya kesulitan dalam berkomunikasi satu sama lain. Berbagai aplikasi lahir dari sebuah kecanggihan teknologi, seperti WhatsApp, Line, Instagram, dan sebagainya. Hampir semua orang menggandrungi beberapa aplikasi tersebut khususnya para wanita remaja yang sekedar ingin menampakan citra diri nya. Beberapa wanita dewasa ikut menggandrungi beberapa aplikasi tersebut tidak hanya sekedar ingin menampakan diri, tetapi juga untuk berbisnis dan sebagainya.

Setiap individu mempunyai maksud dan tujuan dalam penggunaan media sosial itu sendiri. Beragam motivasi untuk hanya sekedar menjalin silaturahim, komunikasi dengan orang lain, mengisi kekosongan waktu, dan mencari tahu bagaimana perkembangan informasi ataupun orang lain. Mempunyai media sosial menyediakan fasilitas layananlayanan untuk menjawab kebutuhan eksistensi bagi penggunanya. Bukan hanya para remaja yang menggunakan media sosial sebagai tempat eksistensinya, tetapi para wanita dewasa pun ingin mengaplikasikan eksistensi dirinya melalui status foto, video, maupun komentar orang lain (Della, 2019).

Adanya media sosial di semua kalangan, menciptakan tidak adanya ruang privat untuk melebur dengan ruang publik. Adanya pergeseran budaya entah itu di kalangan remaja dan orang dewasa, para ibu rumah tangga khususnya sudah tidak gaptek lagi untuk mengupload 
segala aktifitas pribadinya untuk di sampaikan kepada rekan-rekannya melalui akun media sosial dalam memunculkan citra diri dan juga identitas diri (Afriluyanto, 2017).

Seperti diketahui majunya pertumbuhan teknologi, khususnya media sosial tentu saja menghadiahkan banyak sekali dampak, baik dampak yang mengarah ke positif maupun ke arah yang lebih negatif. Apabila berbicara mengenai dampak positif apa yang dilahirkan media sosial terhadap wanita dewasa tentunya banyak, dalam ranah pendidikan mahasiswa akan lebih mudah dalam memperbaharui informasinya dalam kegiatan belajarnya, memudahkan sarana untuk berdiskusi dengan teman-temannya, dan juga dapat berinteraksi dengan publik, serta mengelola jaringan pertemanan. Media adalah salah satu perantara atau sebagai tanda bukti dari hadirnya eksistensi diri manusia. Individu mengutarakan dengan hadirnya teknologi maka dirinyapun ada, yang biasa disebut sebagai the extension of man. Dalam lingkup manusia itu sendiri, manusia mengembangkan dan juga berperoses diri melalui berbagai cara yang menentukan tingkat peradaban dan masanya (Straubhaar, 2006).

Dan jika kita berbicara mengenai dampak negatif apa yang dilahikan dari pada maniak gadget khususnya pada wanita dewasa juga sangatlah banyak. Pribadi yang menggunakan bukan untuk menggali informasi belajar tetapi untuk kesibukan di media sosial lainnya misalnya entah itu facebok, Instagram, Tik-Tok, Line dan lain sebagainya, cenderung akan lalai bila seseorang tidak bisa membagi waktunya dengan baik. Mereka akan cenderung lupa akan kewajiban mereka entah itu beribadah, makan, berinteraksi dengan dunia nyata dan juga lain sebagainya.

Bila pribadi tersebut tidak bisa membagi waktunya dengan baik maka yang akan terjadi adalah mereka akan kehilangan dunia nyata mereka entah itu berkomunikasi dengan orang tua, berkomunikasi dengan keluarga, bahkan teman-teman nya sekalipun, ia akan lebih asik berteman di dunia maya, Tetapi banyak yang tidak menyadari hal tersebut. Yang mereka banggakan adalah mereka bisa kenal dan berteman dengan orang-orang yang berada di luar sana, sehingga akan membuat intraksi dengan teman sebaya yang selalu berada di sekitarnya, lambat laun akan dilupakan. (Kompas,2020)

Di lihat dari zaman skarang banyak individu kehilangan kepribadiannya, yang mereka perlihatkan sehari-hari dalam bergaul dan juga beriteraksi, entah itu cara berpakayan, berfikir, mengelola keuangan yang terkadang bagi wanita bisa saja secar konsumtif memaki pengeluarannya hanya untuk sekedar di pandang hits oleh lingkugan nya dan juga mendapat mendapat anggapan dari di sekelilinnya.

Tanpa disadari remaja jaman sekarang menutupi identitas dirinya menjadi orang lain. Bahkan mirisnya lagi, kebanyakan individu khususnya wanita pada saat ini, mereka hanya mengenal nama bintang idolanya, sementara para pahlawan yang telah berjuang membela negeri ini, seolah sudah memudar dalam benak para individu, jangankan untuk mengingat apa yang telah dilakukan para pahlawan, sekedar mengingat namanya saja sangat susah untuk diingat terlebih lagi asal pahlawan kita. Sedangkan selebritis-selebritis di luar negeriyang sebenarnya tidak pernah memberikan kontribusi kepada negeri ini,itulah nama yang akan melekat dalam otaknya. Dan akan selalu di sanjung-sanjung bak puteri dan raja . 
Sehingga, hal ini akan mengakibatkanpara remaja akan terlena dengan apa yang menjadi pegangannya saat ini. (Kompas,2020)

Media akan memberikan informasi tanpa ada batasan. Yang terpenting bahwa mereka akan mendapatkan ranting yang tinggi. Media tidak akan peduli, informasi yang di berikan akan berpengaruh positif atau negatifbagi pengguana media. Tetapi dari permasalahan yang terjadi dalam kehidupan remaja, tidak sedikit remaja yang menggunakan media dengan tidak semestinya.karena kecendrungan dari remaja, mereka memiliki rasa keingintahuan tentang sesuatu hal sangatlah tinggi. Sehingga sedikit demi sedikit medialah yang menjadi alat tercepat bagi mereka untuk mendapatkan informasi yang dibutuhkan. Sehingga akan besar pengaruh media terhadap pembentukan karakter dirinya.

Berbicara menegnai karakter masalah karakter merupakan salah satu problem yang sangat menarik dibahas, baik di negara yang sudah maju ataupun negara yang sedang berkembang terlebih negara berkembang, hal ini merupakan masalah yang menjadi perhatian khusus dalam setiap bangsa. (Heri,2018) Hal ini disebabkan karena perkembangan zaman yang semakin maju dan derasnya pengaruh arus globalisasi yang realitanya tidak diiringi dengan penanaman nilai moral di dalam diri seseorang. (Imam,2019) sehingga dampak yang ditimbulkan dalam dunia pendidikan ialah perilaku individu, suka membangkang, tidak patuh, kebiasaan mencuri,hilangnya nilai kejujuran, memudarnya nilai-nilai tanggung jawab, hingga pada perilaku anarkis, seperti aksi-aksi kekerasan, tawuran, narkoba dan lain sebagainya.Menurut Maksudin fenomena ini tentunya tidak akan terjadi apabila peran orang tua guru, tokoh masyarakat beserta Lembaga pendidikan berhasil dalam penanaman dan pengembangan nilai moral yang berlaku dimasyarakat. (Maksudin,2009) Namun orientasi pendidikan nasional yang kita rasakan saat ini lebih menekankan pada aspek kognitif, parsialistik, dan cenderung kurang memberi perhatian terhadap aspek sikap, adapun efek yang ditimbulkan adalah generasi muda kurang memiliki sitem nilai dan sikap. Menurut Suprayogi dalam Mundzir upaya menumbuhkan nilai kebangsaan adalah dengan melalui pendidikan. (Imam,2018)

Pendidikan nilai merupakan penanaman dan pengembangan nilai-nilai dalam diri seseorang. Menurut mardimadja pendidikan nilai sebagai bantuan terhadap peserta didik agar menyadari dan mengalami nilai-nilai dan menempatkannya secara integral dalam keseluruhan hidupnya. Maka dapat kita simpulkan mengenai kontribusi atau peran media dalam pembentukan karakater anak bagsa sangatlah berperan terhadap interaksi dan juga pergaulan individu saat ini. Karena itulah bila pribadi memakai media denganseharusnya jadi itu akan melahirkan kebermanfaatan yang positif di pribadinya dan juga pada kehidupanyya dan begitu pun sebaliknya.

Dari teori dan juga konsep yang sudah di paparkan di atas, relevan dengan hasil-hasil penelitian menyangkut medsos dan juga pembentukan karakter anak, diantaranya adalah, Penelitian Nisa tahun 2016 ia meneliti dampak positif dan juga negatif penggunaan medsos terhadap pendidikan akhlak anak. Terdapat dampak positif dari perkembangan sosmed terhadap pendidik anak-anak yaitu anak dapat beradaptasi, berinteraksi dengan publik dan 
juga mengurusi dan mengelola jaringan teman, serta terciptanya efesiensi mengerjakan tugas-tugas sekolah, dampak negatif nya adalah terciptanya kelalyan pada anak sehingga anak kurang bisa membagi waktu dan juga bersifat malas, menciptakan pribadi anak dengan sangat mudah dalam menyontek tidak jujur terhadap karya sendiri, tidak sopan dalam bepakayan maupun berbicara, sering kali bertengkar dengan melakukan adegan berbahaya seperti adegan kekerasan, perang juga membuat anak alfa dari sekolah karena mereka lebih asik berada di warung internet (warnet) dibandingkan menuntut ilmu, sosial media pun juga menciptakan pribadi anak menghabiskan uang jajan anak sehingga anak dengan berat hati mengambil uang orang tuanya secara diam diam. Oleh karena itu sosial media dapat menyebabkan kemorosatan karakter pada anak.

Selanjutnya penelitian Satri pada tahun 2016 mengungkapkan bahwa media di ciptakan bersama anggapan atau asumsi bahwa individu tiap manusia di rangkai agar bersosialisasi (mahluk sosial), alasannya karena pertumbuhan zaman semakin pesat dan juga maju, yang maksud tujuannya adalah memfasilitasi atau mencukupi user atau penikmat media jejaring sosial tersebut dapat berinteraksi dengan dengan banyak khalayak dengan mudah dan juga praktis. Bericara mengenai pengembangan dinamika karakter dalam ranah masa kini sangat relevan dalam mengatasi krisis moral yang terjadi di dunia pendidikan yang langsung maupun tidak terhubung dengan medsos dan juga karakter pribadi. Berbeda dengan penelitian Marlina pada tahun duaribu delapan belas menghubngkan pengaruh medsos terhadap intensitas hubungan komunikasi orang tua dan juga anak, dengan kesimpulan penelitiannya menggambarkan ada nya rentang atau jarak yang tercipta diantara anak dan pulan orang tua, pada saat orang tua sering memegang gadget ketimbang berinteraksi dengan anaknya pada saat itulah seorang anak tidak cukup untuk merasa di hargai dan juga di anggap, bermain HP boleh-boleh saja asal mengenal waktu dan juga kondisi dimana seorang yang lebih tua harusnya menjadi panutan bagi si buah hati.

\section{METODE PENELITIAN}

Pendekatan penelitian yang di gunakan dalam penelitian ini adalah pendekatan kualitatif, dengan metode penelitian library research, yang artinya melacak dan mengumpulkan buku, artikel, dan dokumen yang relevan sesuai pembahasan dalam penelitiaan. Penelitian Library Research ini dilakukan melalui dua tahap. Pertama, mengumpulkan data yang relevan. Kedua, dengan menganalisis data.populasi penelitian ini adalah mahasiswa pascasarjana UIN SUKA. Teknik pengumpulandata dengan melakukan observasi, wawancara bersama mahasiswa Pascasarjana UIN SUKA secara bergantian. Analsis data dilakukan dengan mengacu kepada analisis kualitatif dalam bentuk deskriptif.

\section{HASIL DAN PEMBAHASAN}

Dilihat dari sisi profile UIN SUKA Perguruan Tinggi Agama Islam Negeri (PTAIN) pertama di Indonesia. Nama UIN Sunan Kalijaga diambil dari salah satu kelompok penyebar agama Islam di Jawa, Walisongo yaitu Sunan Kalijaga. Kampus UIN Sunan Kalijaga berlokasi di dekat perbatasan antara Kota Yogyakarta dengan Kabupaten Sleman, 
tepatnya di Jalan Marsda Adisucipto no. 1. UIN adalah salah satu kampus yang menempati Rangking 54 di Indonesia, ranking 1 di antara PTAIN, ranking 3236 di dunia versi Webometrics Februari 2013, dan Rangking 27 di Indonesia versi 4icu . (UIN,2013).

Analisis berkenaan dengan penggunaan medias sosial terhadap nilai karakter di lingkungan UIN sunan Kalijaga memberikan hasil yang sangat bervariasi dari berbagai individu. Adapun kesimpulan atau hasil penelitian menunjukan atau memperlihatkan bahwa dari 23 orang mahasiswa mengemukakan dampak perkembangan teknologi dalam penggunaan medosos seperti HP di kalangan wanita dewasa maka didapat hasil bahwa yang pertama berdasarkan 3 orang perempuan dwasa yaitu inisial IZ, WN, MN mengatakan bahwa medosos di kalangan perempuan dewasa melahirkan dampak positif dan juga negatif yang tidak dapat di pisahkan mereka memaparkan bahwa penggunaan mereka dan kebutuhan mereka terhadap media sosial sangatlah tinggi. Dimana Dalam sehari mereka dapat menghabiskan waktu kurang lebih 10 jam untuk mengskroling media sosial khusus nya Instagram dan juga Status wa, berbicara menegenai masalah negatif mereka mengemukakan adanya sifat konsumtif pada diri mereka. Dimana sesuatu hal yang kadang tidak terlalu butuh tetapi mereka melihat di tangkpan layar IG begitu menarik perhatian mereka hingga pada ahirnya membeli entah itu tas, sepatu, jaket dan barang barang lainnya. Selain itu mereka memaparkan adanya teknologi media sosial mampu membekukan hubungan sosial dengan lingkungan sekitar.

Berbeda dengan ID, ER, dan WR ereka adalah orang yang cukup aktif dalam media sosial, meeka cenderung jarang untuk selalu meng up fasion mereka di media sosial tapi mereka tidak memungkiri dengan danya media sosial mengubah pola pikir mereka tentang kehidupan diman bila berbicara mengenai dampak negatif yang dilahirkan adalah adanya rasa minder dan juga rendah diri terhadap pencapayan pencapayan atau prestasi orang lain, selain itu pula ada nya rasa ingin mencapai tubuh yang ideal diman mereka mendefiniskan cantik adalah putih, tinggi, semampai, dan tidak gemuk. Lalu berbicara mengenai dampak positifnya mereka memaparkan bahwa banyak kemudahan yang di rasakan seperti memudahkan informasi dimana terkadang mereka bingung akan pergi berlibur kemana tetapi dengan melihat media yang sedang hits mereka bisa langsung mengetahui nya. Begitupun dengan pendidikan mereka dengan mudah mendapatkan informasi dan juga teman disana.

Selanjutnya IN, SR, HM, WR, IS, dan EL beropini juga bahwasannya perubahan siklus teknologi amat berperan pentin dalam anyak lini masyarakat utama nya bagi para pelajar yang meringankan mereka dalam menggali informasi pembelajaran. Tetapi mereka pula berkomentar akan akibat yang di timbulkan khususnya negatif yang sangat sering ditemui di lapangan media sosial acap kali dijadikan menjalin hubungan pada akhirnya banyak sekali para pelajar yang tenggelam dalam kenakalan dan sikap menyimpang contohnya saja pornografi. Selnjutnya RT, RO, RS, dan RV mengemukakan komentar nahwasanya perkembangan teknologi pada dasarnya membawa faedah yang sangat besar, namun bagi kalangan tertentu jika ditelusuri terhadap penggunaan medsos cenderung 
membawa dampak negatif khususnya di kalangan wanita dewasa lebih cenderung bersifat konsumtif terhadap barang barang yang di perlukan, meniru segala perkembanagn seakan tidak ingin kalah, apalagi timbulnya cuitan yang melecehkan seseorang demi membela seseorang mungkin tanpa merekasadari sudah menyinggung hati yang lain.

Kemudian sl. Sv, dan SR berkomentar dampak dari medsos disadari telah mengurangi esensi karakter di kalangan tertentu diantaranya yaitu sangat merosotnya sikap atau prilakau sosial dalam menjalin pertemanan dan persahabatan di sebabkan mereka terlalu sibuk bersama dunia nya sendiri, kata kasar sering terlontar dalam setiap cuittan statsus dan mereka alami dinamika gejolak emosi dengan teman sebaya ataupu dengan orang yang lebih tua darinya, sekarang menggunakan media sosial untuk mengekspos kehidupan pribadi demi pamoritas diri dan belombalomba dalam memamerkan tampilan di medsos, termasuk dalam memilih pakaian yang pantas untuk dikenakan.

\section{SIMPULAN}

Berdasarkan analisa yang sudah di lakukan didapati bahwasannya dari dimensi perkembangan dan pesatnya teknologi memberikan beberapa dampak, ialah dampak negatif dan juga dampak positif terutama di kalangan wanita dewasa yaitu diantaranya pertama,dampak positif pesatnya teknologi dalam ranah pendidikan sudah berani membuat dan menciptakan aktipitas belajar yang baik, sangat mengefisiensikan waktu dalam menggali informasi, sangat memudahkan mahasiswa mencari sumber-sumber belajar. Penerapan teknologi khususnya dalam ranag pengajaran dan pembeljaran menciptakan mahasiswa lebih bersemangat dan lebih menarik untuk belajar. Sedangkan point ke dua adalah dampak negatifnya adalah timbul dari kalangan wanita dewasa menjadi sangat konsumtif terhadap keinginan, karena mudahnya mengakses toko onlain, menurunnya nilainilai karakter utama nya dari interaksi sosial, rendahnya intensitas komunikasi dengan lingkungan sekitar, tingkat kepedulian yang rendah, kemajuan teknologi disalah gunakan untuk games yang membuat lupa diri.

\section{DAFTAR PUSTAKA}

Afriluyanto, Tegar Roli. (2018). Fenomena Remaja Menggunakan Media Sosial Dalam Membentuk Identitas. KOMUNIKA: Jurnal Dakwah Dan Komunikasi 11, no. 2: 18497. https://doi.org/10.24090/komunika.v11i2.1365.

Amanda, Della. (2019). Penggunaan Media Sosial Pada Ibu Rumah Tangga Dalam Tinjauan Teori Dramaturgi Di Kota Surabaya.. http://lib.unair.ac.id.

Amanda, Della. (2019). Penggunaan Media Sosial Pada Ibu Rumah Tangga Dalam Tinjauan Teori Dramaturgi Di Kota Surabaya. http://repository.unair.ac.id/87337/.

Connaway dan Lynn Silipigni. (2010) Basic Research Methods for Librarians. California: Libraries Unlimited.

Felita, Pamela, Christine Siahaja, Vania Wijaya, Gracia Melisa, Marcella Chandra, and Rayini Dahesihsari. (2016). Pemakaian Media Sosial Dan Self Concept Pada Remaja. 
78 | Fauziatunisa - Penggunaan Media Sosial ...

Jurnal Ilmiah Psikologi 5, no. 1: 30-41.

https://id.wikipedia.org/wiki/Universitas_Islam_Negeri_Sunan_Kalijaga_Yogyakarta

https://www.kompasiana.com/hendriana1994/5535a1cf6ea834370fda42ef/pengaruhdasyat-media-terhadap-pembentukan-karakter-remaja

Heri Cahyono. (2017). Pendidikan Karakter: Strategi Pendidikan Nilai dalam Membentuk Karakter Religius", Jurnal, Ri'ayah, Vol. 01, no.02 Juli-Desember.

Imam Mundzir Al Asy’ari, “Implementasi Pendidikan Nilai-Nilai KH. Hasyim Asy’ Ari di Madrasah

Mu'Allimin Pesantren Tebuireng Jombang", tesis, fakultas ilmu tarbiyah dan keguruan, UIN Sunan Kalijaga.

Maksudin. (2009). Pendidikan Nilai Komprehensif Teori dan Praktik, (Yogyakarta: UNY Press. 